\title{
Current Practices in Undergraduate Student Mentoring
}

Derek Jeske and Denise Rode

Mentoring, though defined differently in various fields of study, has become an important tool for college and universities to ease the transitioning of first year students. This article explores the concept of mentoring and highlights some of the programs that can be found on some of our colleges and universities. Though most mentoring programs have been in existence for fewer than ten years, many of these programs are reporting anecdotal evidence of its successful enhancement of students' academic abilities, interpersonal skills, and individual development.

Mentoring programs can serve important roles for first year students on college and university campuses across the nation. Mentors usually are members of the faculty or professional staff, but may also include graduate or upper-division students, who volunteer time and knowledge to ease new students' transitions from high school to college. Mentor-protégé pairings may be made before students matriculate, or matches can be made at a meeting when students arrive on campus. The goal for the mentoring process is to develop and maintain a helping relationship with the student at least through the initial college adjustment and increasingly for the student's entire college stay.

Mentoring has been defined differently in the fields of psychology, human development, human resource management, and education. However, the overriding purpose of mentoring in each discipline has been the professional and/or personal development of the protégé or mentee (Luna and Cullen, 1994).

The concept of mentoring was introduced into the educational arena through the research of D. Levinson, Darrow, Klein, M. Levinson and McKee (1978), whose studies emphasized the importance of mentoring relationships in young men's transitions to adulthood. Erikson (1963) included the mentoring concept in his theory as part of the generativity stage of one's life, postulating that it is a significant life task for one generation to guide the next.

From this beginning, educational institutions have expanded the concept to create today's mentoring programs. These programs seek to enhance the talents of individuals within academe, promote students' professional growth, and provide benefits to the college or university through greater student involvement and retention (Luna and Cullen, 1995).

Levinson et al. (1978) defined the nature of the mentor as serving as:

- a teacher, by enhancing an individual's skills and intellectual development;

- a sponsor, by facilitating an individual's entry and advancement;

- a host and guide, by welcoming the individual into a new educational and social

Derek Jeske is a graduate student and Program Coordinator at Northern Illinois University. djeske@niu.edu

Denise Rode, Ph.D., is Director of Orientation and an adjunct assistant professor in the Department of Counseling, Adult, and Health Education at Northern Illinois University. drode@niu.edu 
world and acquainting the individual with its values, customs, resources, and roles; and

- an exemplar, by providing role modeling behavior.

Mentors have the ability to encourage, intervene, and support the mentee in achieving a successful college life. They may help the mentee gain access to information about various resources that the college or university has to offer. In order for the relationship to be successful, the mentor needs to give specific comments, nurture confidence, and act as a sounding board for the student.

The role of the mentee involves developing a relationship of trust with the mentor. Mentees must have a strong desire to move forward in their lives, educational and career goals, and personal development. The relationship, once formed, should aid the mentee in growing intellectually, socially, and emotionally. For continued development, however, students in mentoring programs must make a commitment to meet with their mentors regularly, an objective emphasized by most programs.

Astin (1993) indicated that next to the peer group, the faculty had the most significant impact on students' undergraduate development. He suggested that universities might negotiate individual contracts with faculty members that would invite them to do more teaching, mentoring, and advising, perhaps rotating these functions with periods of scholarly activity such as research and publishing.

The inspiration and guidance of a good mentor can provide the critical support a new student needs to balance the challenges encountered in the college or university environment. The faculty-undergraduate student relationship also can contribute to the retention of students on college and university campuses, especially for students at risk.

Mentoring programs also have been used to enhance the probability of retaining students from underrepresented groups by helping them succeed in situations in which they may have little or no experience. In universities and colleges where faculty and administrators traditionally are Caucasian and male, minority students often have less access to informal networks and support. Mentoring, therefore, has been an effective approach toward retention of these students by reducing isolation and providing support.

Most mentoring programs supplement other services offered to new students. In a study by Dyson (1995) at Howard University, the focus was on determining the effect of freshman orientation and mentoring programs on student retention. The mentoring relationship was expected to improve the students' performance, enhance selfconfidence, increase satisfaction with college experiences and life, and increase student retention at the university. Contact with mentors was hypothesized to be related to favorable perceptions of the university climate and higher levels of self-confidence for students.

Mentoring programs in diverse forms are becoming prevalent on college and university campuses. Examples of formalized mentoring programs include the following:

- At Cleveland State University, "The Mentoring Program" is a major component of the First Year Experience (FYE). Since 1986, mentoring has been shown to help new students experience a smoother transition to college life. The 
structured relationship provides consistent support, guidance, and concrete help as the student/mentee navigates through the first year at the university. The program is designed to develop strong supportive relationships with faculty and staff.

- Texas Southern University founded a mentoring program, The Black Male Initiative, in 1990 to encourage African American youths to continue their education. The program promotes the values of education and provides other events that bring role models to the forefront. Successful business and community leaders participate, and are reported to provide inspiration to students.

- $\quad$ Four mentoring services for students are available at Northern Illinois University (NIU). "The Mentoring Project" was developed to assist students in adjusting to college life and enriching their educational experiences through informal interaction with other members of the university community. In addition, NIU initiated "CHAMPS/Life Skills," specifically for student-athletes. This program focuses on the developmental needs of this student population. A third mentoring program is run by the Counseling and Student Development Center. Created in 1987, it assists unconditionally admitted African-American freshmen and transfer students in their adjustments during their first year at NIU. In 1999, the "Peer Mentoring Program" matching upper-division students with entering transfer students was initiated by the Provost's Office. This program currently involves 150 peer mentors and 750 new students.

- The First Year Experience Program at Southern Illinois University-Carbondale (SIU-C) offers two mentoring programs for students, both designed to enhance academic success. "Project STEP" (Success Through Experienced Peers) is a mentoring program for incoming students created to provide them opportunities to develop friendships and relationships with experienced SIU-C students. "Project Magic" (Maximize Academic Growth in College) is a faculty/staffmentoring program which offers students the opportunity to develop a friendly and helpful mentoring relationships. SIU-C also offers material on creating mentoring programs with assistance from Student Development.

Most mentoring programs have been in existence for fewer than ten years and are still evolving. The need for more research on the effectiveness of mentoring is evident, although preliminary assessments are promising. Anecdotal evidence would indicate that mentoring programs enhance students' academic ability, interpersonal skills, and individual development, but additional research is needed to confirm this assumption. Optimally, establishing a successful mentor-protégé relationship during the undergraduate experience will encourage students to seek out similar relationships in future educational and career settings, perhaps even culminating in eventual service as mentors for the next generation. 


\section{References}

Astin, A. W. (1993). What matters in college: Four critical years revisited. San Francisco: Jossey-Bass.

Dyson, S. L. (1995). The effectiveness of mentor supplemented freshman orientation: A self-concept enhancing retention intervention model. DAI, v56-10A: p3887.

Erikson, E. H. (1963). Adulthood. New York: W.W. Norton.

Levinson, D. J., Darrow, C. N., Klein, E. B, Levinson, M. A. and McKee, B. (1978). The seasons of a man's life. New York: Knopf.

Luna, G; and Cullen, D. L. (1995). Empowering the faculty: Mentoring redirected and renewed. ASHE-ERIC Higher Education Reports. v ('95): pp.1-87.

New Student and Family Parent Programs. Student development. Southern Illinois University-Carbondale. Success through experienced peers. (1999). [Brochure]. Carbondale, IL.

New Student and Family Parent Programs. Student development. Southern Illinois University-Carbondale. Maximize academic growth in college. (1999). [Brochure]. Carbondale, IL. 